\title{
RANCANG BANGUN APLIKASI VIRTUAL CLASS SEBAGAI MEDIA PEMBELAJARAN MENGGUNAKAN FRAMEWORK CODEIGNITER (STUDI KASUS : UNIVERSITAS CIC CIREBON)
}

\author{
GaganSuganda', Noni Apriliani Yulia Putri², Ridho Taufiq ${ }^{3}$, Victor Asih ${ }^{4}$ \\ Universitas Catur Insan Cendekia \\ Jl. Kesambi No. 202, Cirebon \\ e-mail: gagan.suganda98@gmail.com ${ }^{1}$, noniaprilianiyuliaputri@gmail.com ${ }^{2}$, ridho.taufiq@cic.ac.id ${ }^{3}$, \\ victor.asih@cic.ac.id ${ }^{4}$
}

\begin{abstract}
ABSTRAK
Universitas CIC merupakan salah satu Universitas dalam bidang komputer di Cirebon yang selalu berupaya untuk ikut andil dalam mengembangkan media pembelajaran khususnya di era revolusi industri 4.0. Salah satu upaya yang dilakukan adalah memperbarui fasilitas proses pembelajaran di Universitas CIC untuk menunjang pembelajaran jarak jauh dengan e-learning. Ada beberapa faktor yang menyebabkan pelaksanaan perkuliahan tidak efektif untuk dilaksanakan secara tatap muka, yaitu pertama adalah masalah geografis. Masalah geografis disini adalah terhambatnya pelaksanaan pembelajaran dikarenakan rentang jarak yang jauh untuk dosen maupun mahasiswa dapat hadir pada kegiatan pembelajaran secara langsung di kampus. Kedua, permasalahan bagi kelas yang belum mendapatkan ruang kelas dikarenakan penuhnya jadwal perkuliahan. Tentu, hal tersebut dapat menjadi hambatan bagi dosen pengajar dan para mahasiswa untuk dapat melaksanakan pembelajaran secara langsung pada ruang kelas. Oleh karena itu, diperlukan solusi bagaimana membuat sebuah aplikasi yang dapat memudahkan pihak BAAK dalam mengatur jadwal perkuliahaan yang penuh serta memudahkan dosen maupun mahasiswa dalam melakukan pembelajaran jarak jauh. Penelitian ini membahas tentang aplikasi virtual class sebagai media pembelajaran dengan menggunakan UML (Unified Modeling Language) sebagai tools dalam analisis dan perancangan, serta bahasa pemrograman PHP Hypertext Preproccessor dengan framework CodeIgniter, dan MySQL sebagai media penyimpanan datanya. Hasil dari penelitian ini adalah Aplikasi Virtual Class yang bertujuan untuk memudahkan BAAK dalam mengatur jadwal perkuliahaan yang penuh serta memudahkan dosen maupun mahasiswa dalam melakukan pembelajaran jarak jauh. Output yang dihasilkan adalah fasilitas aplikasi virtual class yang memudahkan pihak BAAK dalam mengatur jadwal perkuliahan yang penuh serta memudahkan dosen maupun mahasiswa dalam melakukan pembelajaran jarak jauh.
\end{abstract}

Kata Kunci : Aplikasi Virtual Class, E-Learning, CodeIgniter

\begin{abstract}
CIC University is one of the universities of computer field in Cirebon which always strives to take part in developing learning media especially in the era of the industrial revolution 4.0. One of the efforts made is updating the learning process facilities at CIC University to support distance learning using e-learning. There are several factors that cause the implementation of lectures to be ineffective face-to-face, namely the first is geographical problems. The geographic problem here is the obstruction of the implementation of learning due to long distances for lecturers and students to attend learning activities directly on campus. Second, the problem for classes that have not yet got a classroom is due to the full class schedule. Of course,
\end{abstract}

Rancang Bangun Aplikasi Virtual Class Sebagai Media Pembelajaran Menggunakan Framework CodeIgniter Studi Kasus Universitas CIC Cirebon (Gagan Suganda, Noni Apriliani Yulia Putri, Ridho Taufiq, Victor Asih) 
this can be an obstacle for lecturers and students to be able to carry out learning directly in the classroom. Therefore, a solution is needed how to make an application that can make it easier for BAAK in managing full lecture schedules and making it easier for lecturers and students to do distance learning. This study discusses virtual class applications as a learning medium using UML (Unified Modeling Language) as a tool in analysis and design, as well as the PHP Hypertext Preproccessor programming language with CodeIgniter framework, and MySQL as data storage media. The result of this research is a Virtual Class Application which aims to facilitate BAAK in managing full lecture schedules and making it easier for lecturers and students to do distance learning. The resulting output is a virtual class application facility that makes it easier for BAAK to manage full lecture schedules and make it easier for lecturers and students to do distance learning.

Keywords : Virtual Class Application, E-Learning, CodeIgniter.

\section{PENDAHULUAN}

Pesatnya perkembangan teknologi informasi dan komunikasi di era revolusi industri 4.0 mempengaruhi beberapa aspek kehidupan manusia, salah satunya di dunia pendidikan yang menuntut untuk ikut andil dalam mengembangkan media pembelajaran. Salah satu penerapan teknologi di era revolusi industri 4.0 dalam dunia pendidikan adalah virtual class.

Universitas CIC merupakan salah satu perguruan tinggi yang terletak di kota Cirebon dan merupakan perguruan tinggi dalam bidang komputer dan manajemen. Sebagai salah satu perguruan tinggi dalam bidang komputer, tentunya mendapatkan dampak dari era rovolusi industri 4.0 dalam mengembangkan teknologi khususnya dalam media pembelajaran. Dari pembelajaran tatap muka (konvensional) menuju pendidikan yang lebih terbuka dengan memanfaatkan teknologi informasi dan komunikasi sebagai media pembelajaran (e-learning).

Penerapan e-learning dalam perkuliahan di Universitas CIC sudah sering dilaksanakan dengan menggunakan bantuan aplikasi e-learning seperti Edmodo dan Google Classroom. Akan tetapi, belum adanya perancangan dan pembangunan aplikasi e-learning yang dirancang oleh mahasiswa khusus untuk menunjang pembelajaran jarak jauh. Selain itu, terdapat beberapa faktor yang menyebabkan pelaksanaan perkuliahan tidak efektif untuk dilaksanakan secara tatap muka, yaitu pertama adalah masalah geografis. Masalah geografis disini adalah terhambatnya pelaksanaan pembelajaran dikarenakan rentang jarak yang jauh untuk dapat hadir pada kegiatan pembelajaran secara langsung di kampus. Kedua, permasalahan bagi kelas yang belum mendapatkan ruang kelas dikarenakan penuhnya jadwal perkuliahan. Tentu, hal tersebut dapat menjadi hambatan bagi dosen pengajar dan para mahasiswa untuk dapat melaksanakan pembelajaran secara langsung pada ruang kelas.

Dari masalah tersebut maka dibuatlah Aplikasi dengan judul Aplikasi Rancang Bangun Aplikasi Virtual Class Sebagai Media Pembelajaran Menggunakan Framework CodeIgniter Studi Kasus Universitas CIC Cirebon.

\section{KAJIAN PUSTAKA}

Menurut Kamus Besar Bahasa Indonesia (2008) virtual class adalah sebuah penerapan proses pembelajaran yang dilaksanakan secara online menggunkan bantuan internet, dimana proses pembelajaran dapat dilaksanakan tanpa terbatas oleh ruang dan waktu. Sedangkan kelas (class) adalah ruang tempat belajar di sekolah. Kelas berfungsi sebagai tempat untuk kegiatan tatap muka dalam proses kegatan belajar mengajar (KBM). Sehingga, pengertian virtual class adalah sebuah penerapan proses pembelajaran yang dilaksanakan secara online menggunkan bantuan internet, dimana proses pembelajaran dapat dilaksanakan tanpa terbatas oleh ruang dan waktu.

Darisman dan Haldi (2019) penelitiannya tentang Pengembangan Virtual Class Matematika Berbasis Web Menggunakan Moodle dan Wordpress di Universitas Muhammadiyah Jember yang pembahasannya berfokus pada pengembangan virtual class menggunakan moodle dan wordpress untuk menghasilkan virtual class yang dinamis, interaktif dan praktis.

Rhomdani (2016) penelitiannya tentang Optimalisasi E-Learning berbasis Virtual Class dengan Google Classroom sebagai Media Pembelajaran Fisika merupakan jurnal referensi kedua yang pembahasannya berfokus pada langkah-langkah pengoptimalisasian google classroom sebagai media pembelajaran. 
Nurfalah (2019) penelitiannya tentang Pengembangan Media Pembelajaran Berbasis Virtual Class Berbantuan Google Drive yang pembahasannya berfokus pada pembuatan aplikasi virtual class sebagai strategi untuk meningkatkan kemandirian belajar mahasiswa berbantuan google drive.

Betha Sidik (2018) dalam bukunya yang berjudul Framework CodeIgniter 3, CodeIgniter merupakan framework pengembangan aplikasi dengan menggunakan PHP, yang menjadikan pembuatan web menjadi lebih sistematis. Pemrogram tidak perlu membuat program dari awal, karena CodeIgniter menyediakan sekumpulan librari dan fungsi yang diperlukan untuk menyelesaikan pekerjaan dengan menggunakan antarmuka dan struktur logika yang sederhana untuk mengakses librarinya.

Aplikasi menurut Jogiyanto, dalam bukunnya yaitu Aplikasi adalah penggunaan dalam suatu komputer atau pernyataan yang disusun sehingga komputer dapat memproses input menjadi output. (Hartono, 1999).

\section{METODE PENELITIAN}

\subsection{Metode Pengumpulan Data}

\section{Observasi}

Melakukan peneliatian ke Universitas CIC dengan menganalisis mengenai bagaimana proses pembelajaran e-learning antara dosen dan mahasiswa yang biasanya dilaksanakan.

2. Wawancara

Penulis mengajukan pertanyaan secara langsung kepada Dosen untuk memperoleh data yang diperlukan.

\subsection{Metode Pengembangan Perangkat Lunak}

Metode yang digunakan adalah metode waterfall, yaitu sebuah metode pengembangan software yang bersifat sekuensial dan terdiri dari 5 tahap yang saling terkait dan mempengaruhi seperti terlihat pada gambar berikut:

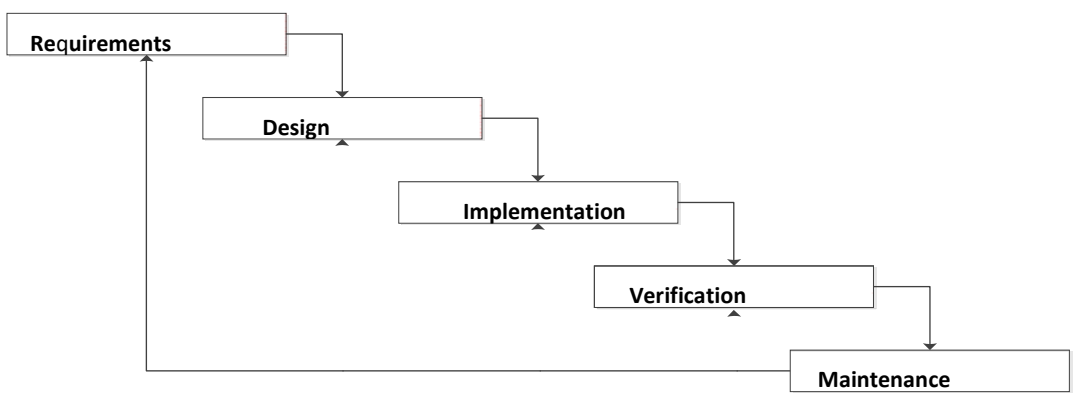

Gambar 1. Metode Waterfall

1. Requirements (Analisa Kebutuhan Sistem)

Proses pengumpulan data dilakukan dengan cara observasi dan wawancara langsung dengan pihak marketing mengenai proses penerimaan mahasiswa baru yang terjadi sekarang sehingga penulis dapat mengajukan sistem usulan yang akan dibuat. Tahapan ini menghasilkan data yang dibutuhkan dalam pembuatan sistem.

2. Design (Desain)

Tahap selanjutnya yaitu proses desain dimana penulis merancang serta menentukan alur sistem secara keseluruhan dengan menggunakan Unified Modelling Language (UML) yang meliputi Use Case Diagram, Flow of Event, Activity Diagram, Sequence Diagram, Class Diagram, struktur program, desain input dan output, serta tampilan program. Tahapan ini menghasilkan data yang menggambarkan aktivitas setiap user didalam sistem. 
3. Implementation (Implementasi)

Penulis menerjemahkan keseluruhan desain sistem yang telah disusun menjadi kode-kode program sehingga dihasilkan sistem secara keseluruhan.

4. Verification (Verifikasi)

Sistem yang sudah dibuat akan di tes untuk menguji apakah sistem tersebut telah berfungsi dengan baik sesuai dengan tahap analisis dan desain yang telah dilakukan. Tahapan ini menghasilkan pengkajian ulang dan perbaikan sistem apabila ditemukan kesalahan.

5. Maintenance (Perawatan)

Tahap akhir adalah perawatan, dimana penulis melakukan pemeliharaan sistem yang termasuk diantaranya instalasi dan proses perbaikan sistem apabila ditemukan adanya kesalahan/bug yang tidak ditemukan pada tahap verifikasi. Tahapan ini menghasilkan sistem yang lebih baik dan sempurna.

\section{HASIL DAN PEMBAHASAN}

\subsection{Analisa Sistem Usulan}

Analisa ini akan menjelaskan bagaimana sistem yang akan diusulkan mengenai pembelajaran $e$ learning (virtual class) di Universitas CIC. Analisa sistem usulan ini menggunakan tools UML (Unified Modeling Language) yang terdiri dari: Use Case Diagram, Activity Diagram, Sequence Diagram, Class Diagram, dan tampilan antar muka.

a. Use Case Diagram

1. Use Case Diagram BAAK

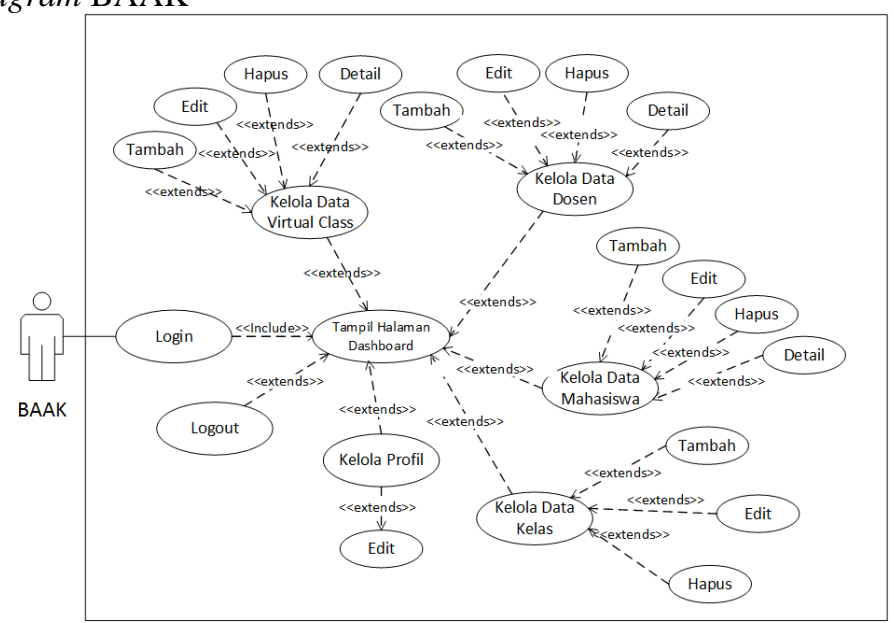

Gambar 2. Use Case Diagram Bagian BAAK

2. Use Case Diagram Dosen

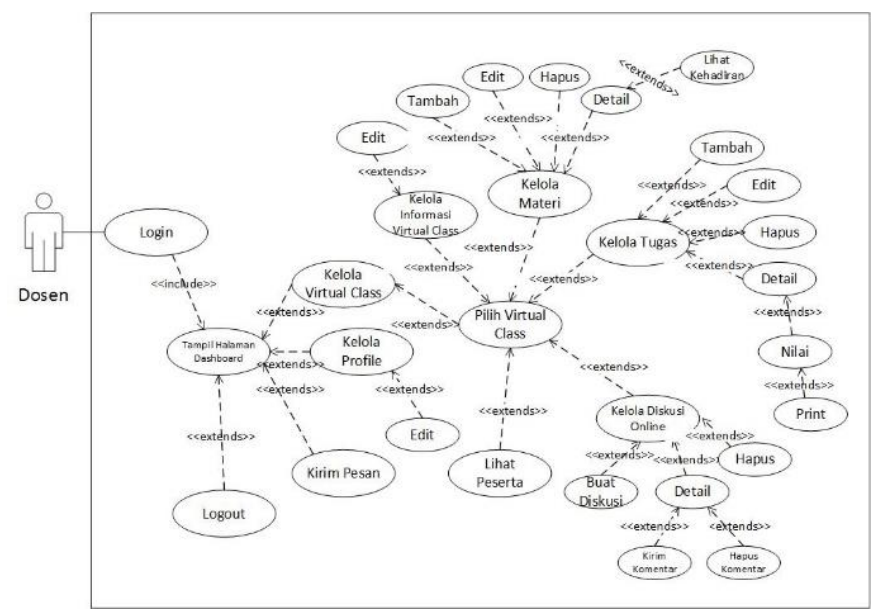

Gambar 3. Use Case Diagram bagian Dosen 
3. Use Case Diagram Mahasiswa

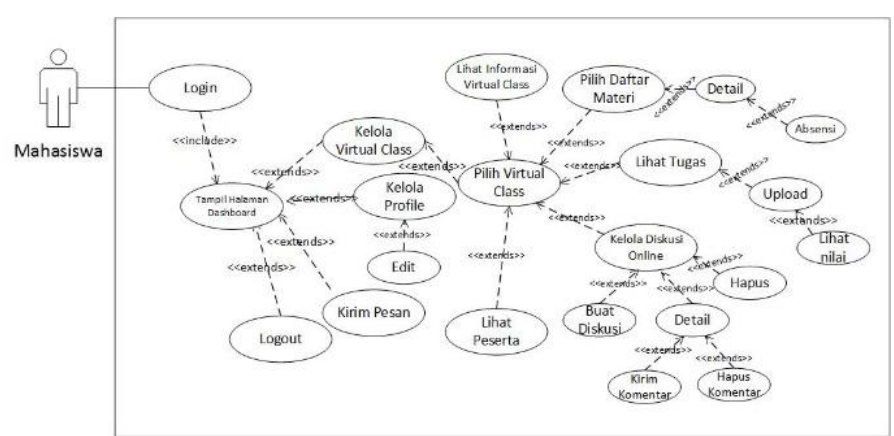

Gambar 4. Use Case Diagram bagian Mahasiswa

b. Activity Diagram

1. Activity Diagram BAAK

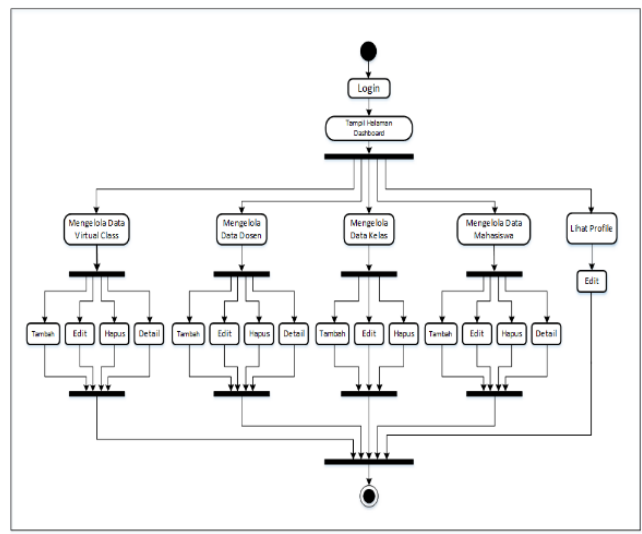

Gambar 5. Activity Diagram Bagian BAAK

2. Activity Diagram Dosen

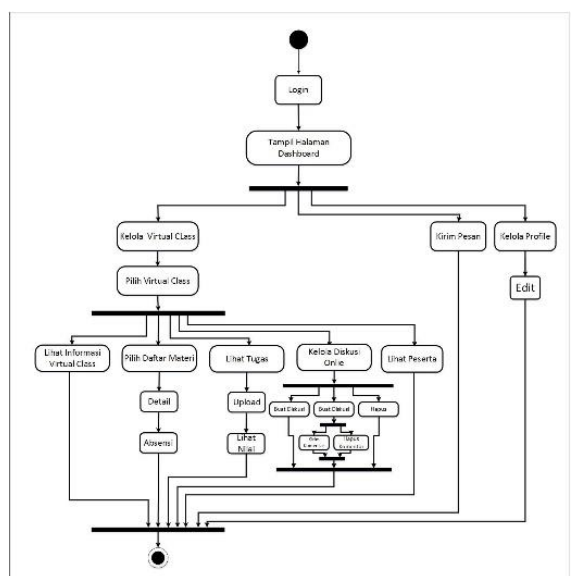

Gambar 6. Activity Diagram Bagian Dosen

Rancang Bangun Aplikasi Virtual Class Sebagai Media Pembelajaran Menggunakan Framework CodeIgniter Studi Kasus Universitas CIC Cirebon(Gagan Suganda, Noni Apriliani Yulia Putri, Ridho Taufiq, Victor Asih) 
3. Activity Diagram Mahasiswa

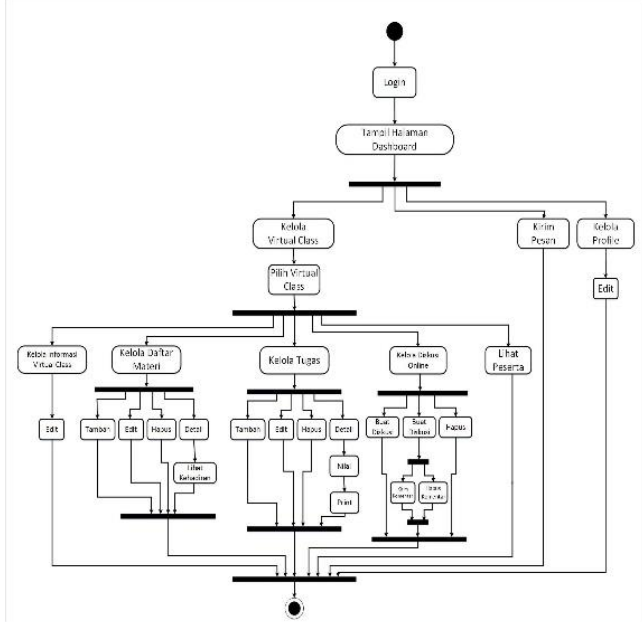

Gambar 7. Activity Diagram Bagian Dosen

c. Sequence Diagram Bagian BAAK

1. Sequence Diagram Kelola Data Virtual Class

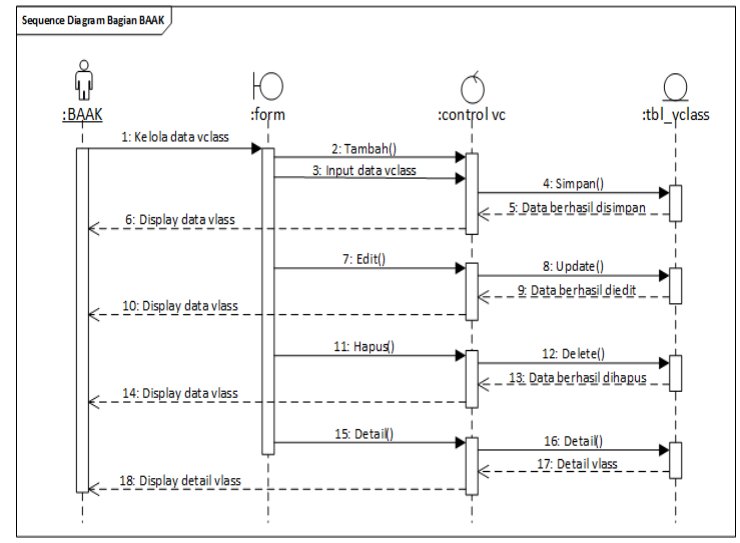

Gambar 8. Sequence Diagram Kelola Data Virtual Class

d. Sequence Diagram Bagian Dosen

1. Sequence Diagram Kelola Materi

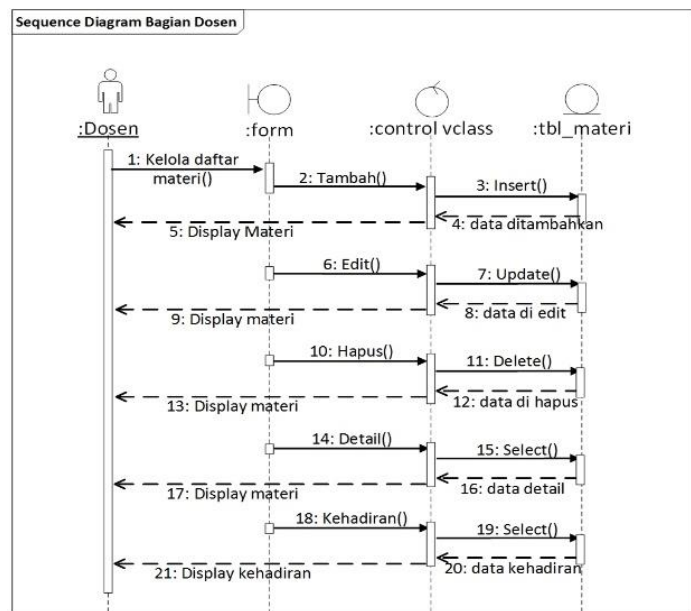

Gambar 9. Sequence Diagram Kelola Materi 
2. Sequence Diagram Kelola Tugas

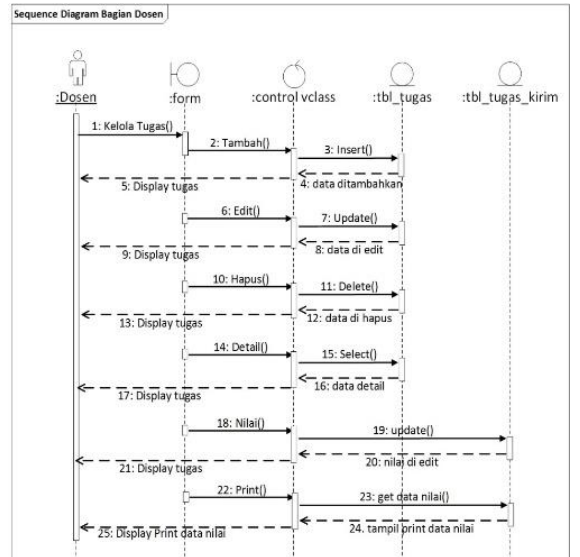

Gambar 10. Sequence Diagram Kelola Tugas

3. Sequence Diagram Kelola Diskusi Online

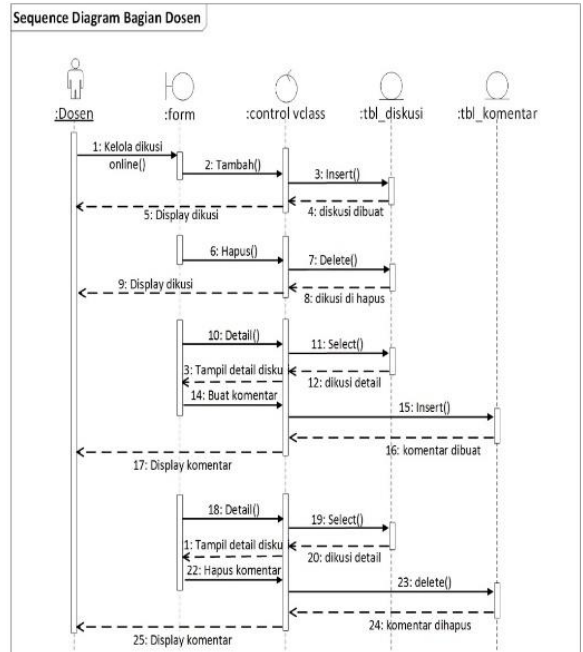

Gambar 11. Sequence Diagram Kelola Diskusi Online

4. Sequence Diagram Kirim Pesan

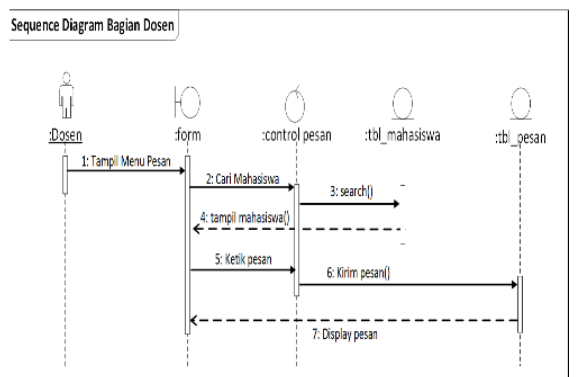

Gambar 12. Sequence Diagram Kirim Pesan

Rancang Bangun Aplikasi Virtual Class Sebagai Media Pembelajaran Menggunakan Framework CodeIgniter Studi Kasus Universitas CIC Cirebon (Gagan Suganda, Noni Apriliani Yulia Putri, Ridho Taufiq, Victor Asih) 
e. Sequence Diagram Bagian Mahasiswa

1. Sequence Diagram Pilih Daftar Materi

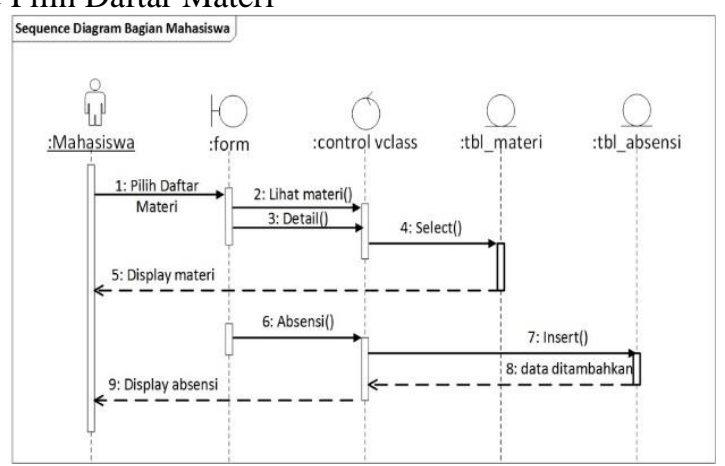

Gambar 13. Sequence Diagram Pilih Daftar Materi

2. Sequence Diagram Lihat Tugas

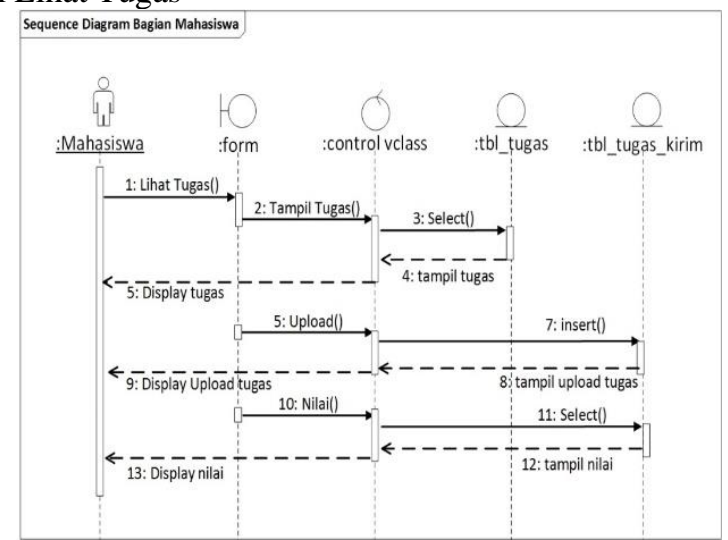

Gambar 14. Sequence Diagram Lihat Tugas

3. Sequence Diagram Kelola Diskusi Online

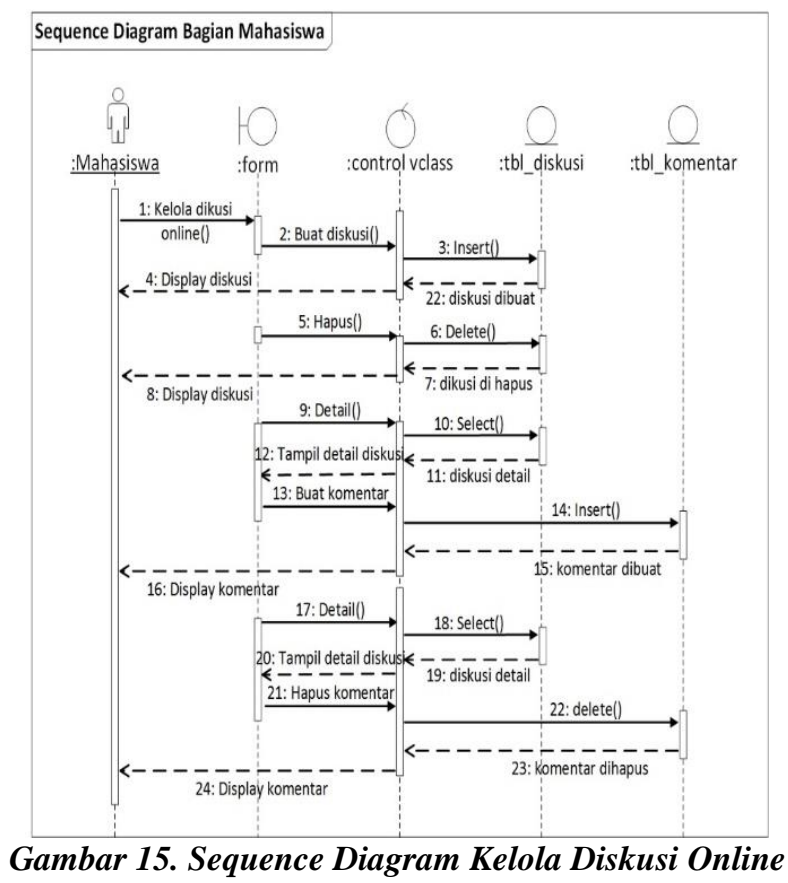




\section{Sequence Diagram Kirim Pesan}

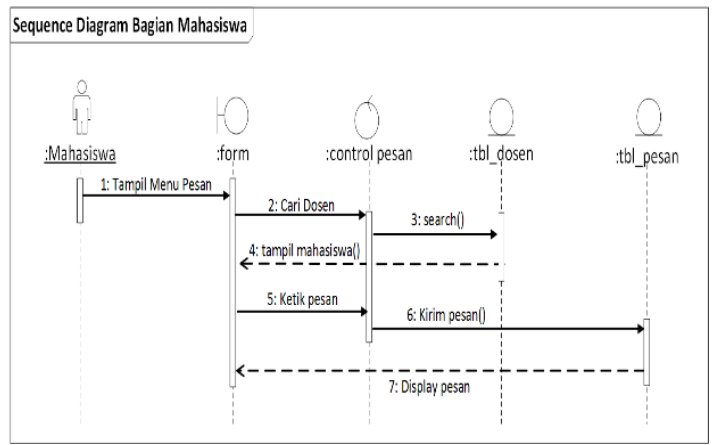

Gambar 16. Sequence Diagram Kirim Pesan

f. Class Diagram

Berikut ini class diagram dari sistem Virtual Class di Universitas CIC :

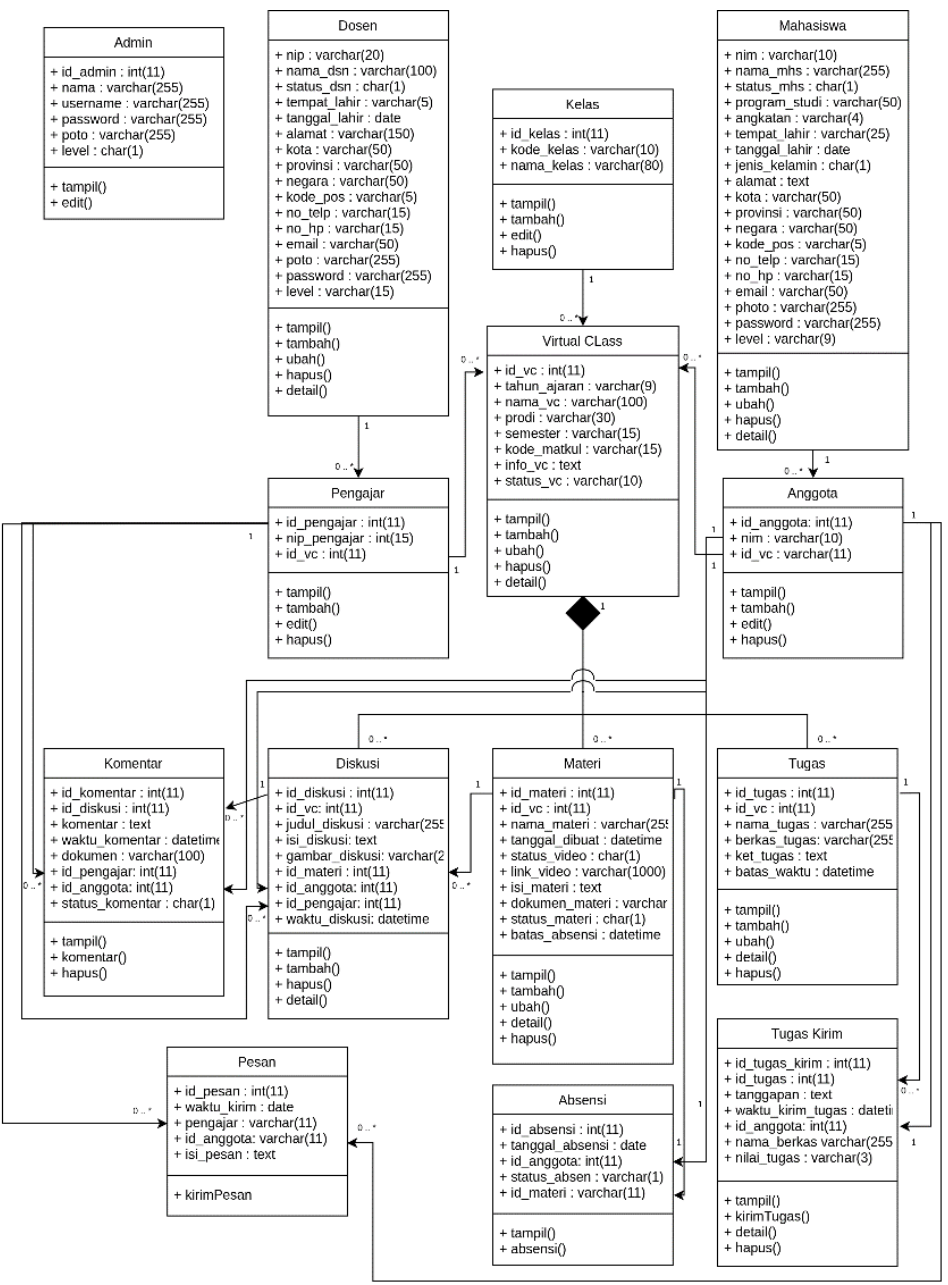

Gambar 17. Class Diagram

Rancang Bangun Aplikasi Virtual Class Sebagai Media Pembelajaran Menggunakan Framework CodeIgniter Studi Kasus Universitas CIC Cirebon (Gagan Suganda, Noni Apriliani Yulia Putri, Ridho Taufiq, Victor Asih) 
4.2. Implemetasi Antar Muka

4.2.1 Halaman Untuk BAAK

a. Halaman Form Login

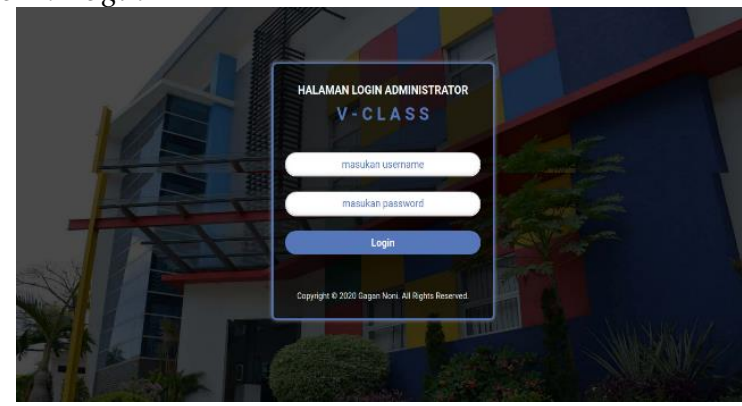

Gambar 18. Halaman Form Login BAAK

b. Halaman Dashboard BAAK

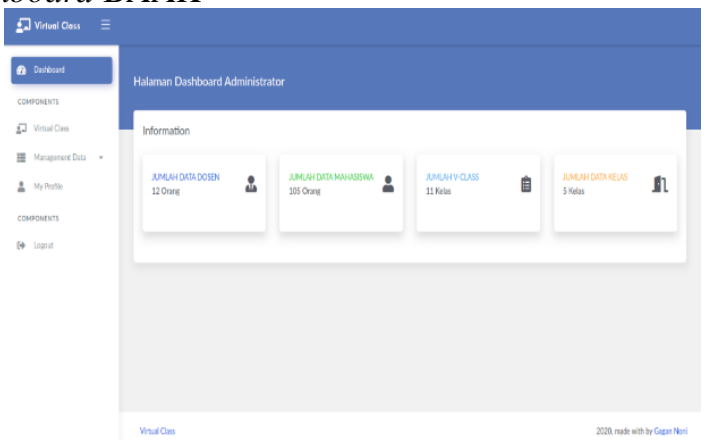

Gambar 19. Halaman Dashboard BAAK

c. Halaman Manajemen Virtual Class

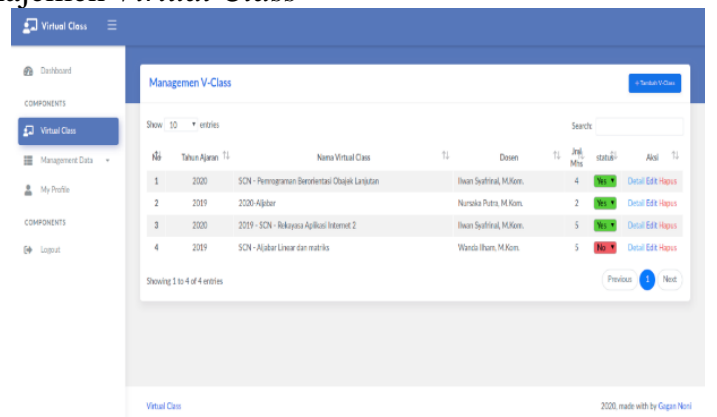

Gambar 20. Halaman Manajemen Virtual Class

\subsubsection{Halaman Untuk Dosen}

a. Halaman Form Login

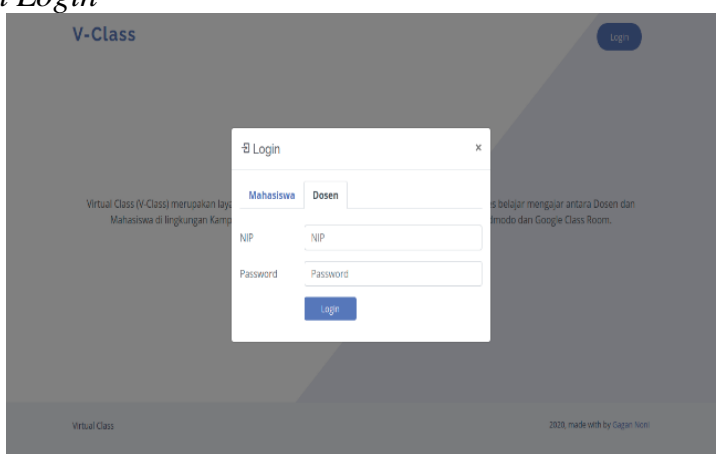

Gambar 21. Halaman Form Login Dosen 
b. Halaman Dashboard Dosen

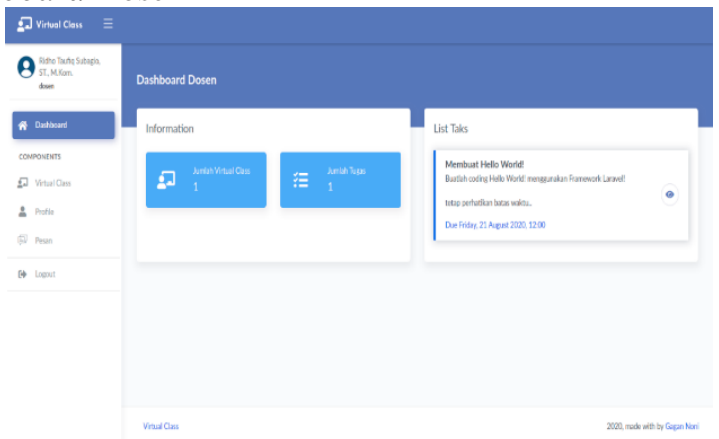

Gambar 22. Halaman Dashboard Dosen

c. Halaman Kelola Materi

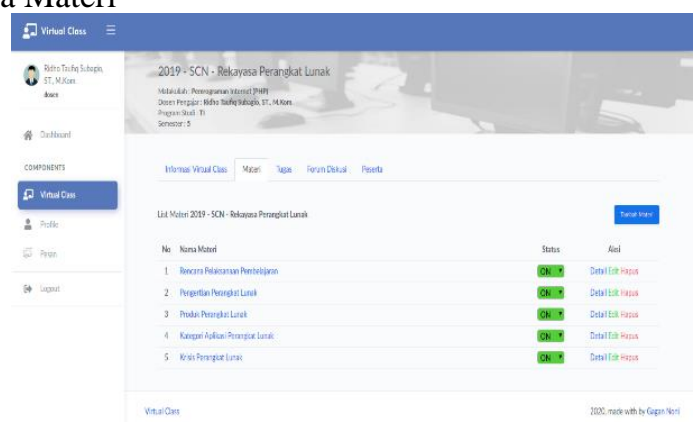

Gambar 23. Halaman Kelola Materi

d. Halaman Kelola Tugas

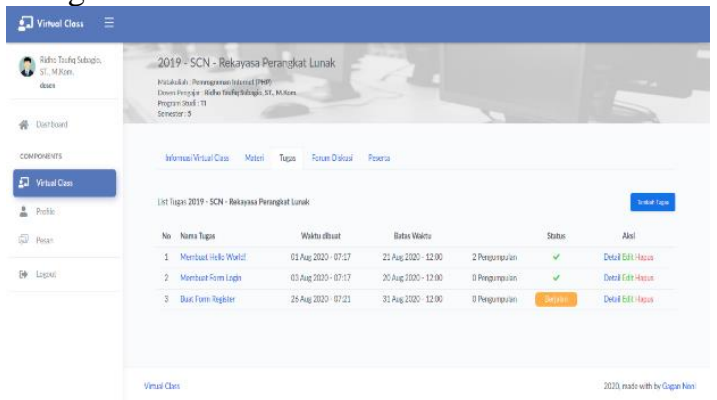

Gambar 24. Halaman Kelola Tugas

e. Halaman Kelola Forum Diskusi

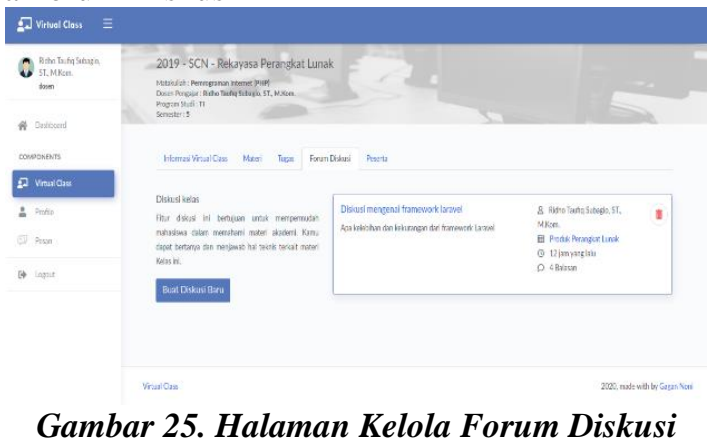

Rancang Bangun Aplikasi Virtual Class Sebagai Media Pembelajaran Menggunakan Framework CodeIgniter Studi Kasus Universitas CIC Cirebon(Gagan Suganda, Noni Apriliani Yulia Putri, Ridho Taufiq, Victor Asih) 
f. Halaman Forum Pesan

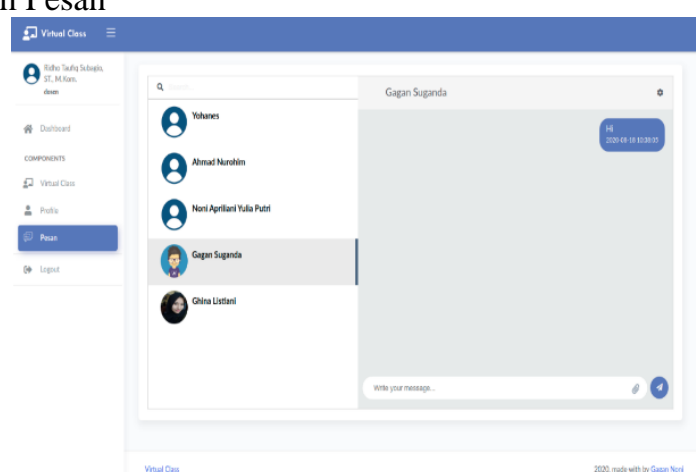

Gambar 26. Halaman Forum Pesan

\subsubsection{Halaman Untuk Mahasiswa}

a. Halaman Form Login

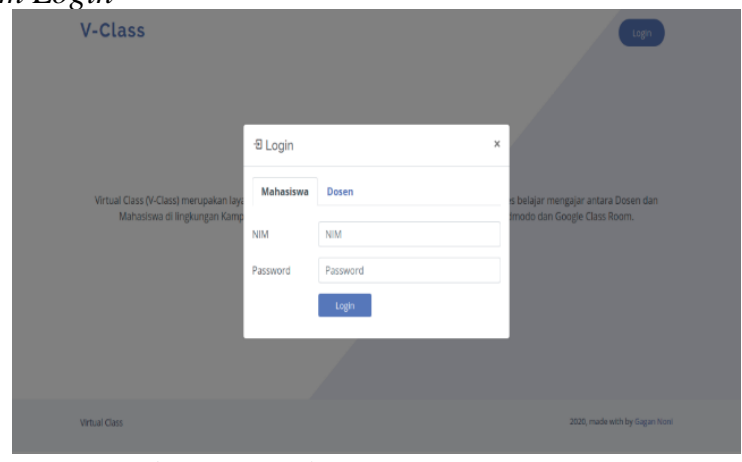

Gambar 27. Halaman Form Login Dosen

b. Halaman Dashboard Mahasiswa

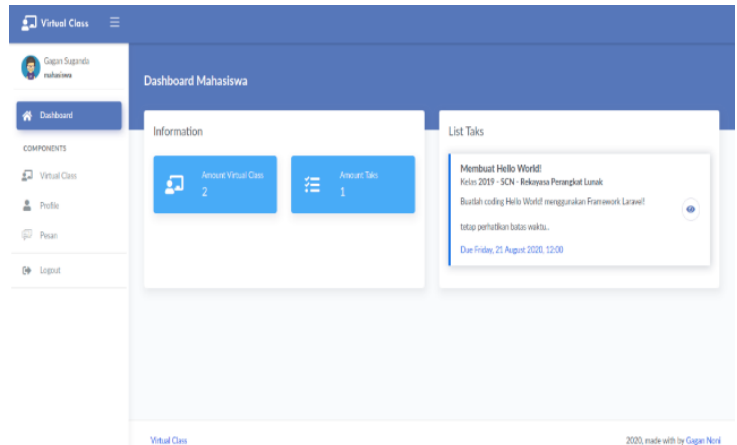

Gambar 28. Halaman Dashboard Mahasiswa

c. Halaman Daftar Materi

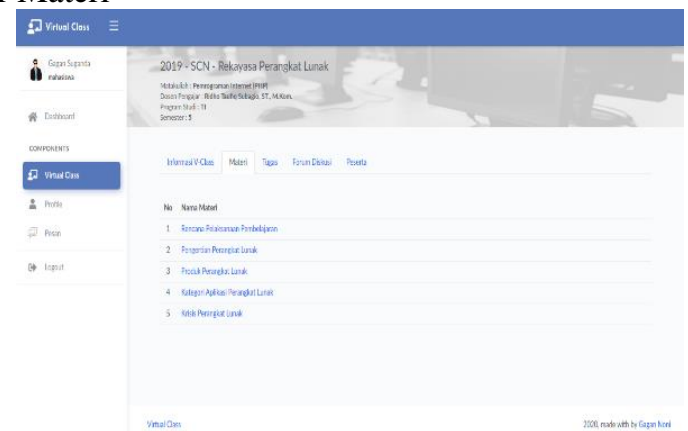

Gambar 29. Halaman Daftar Materi 
d. Halaman Kelola Tugas

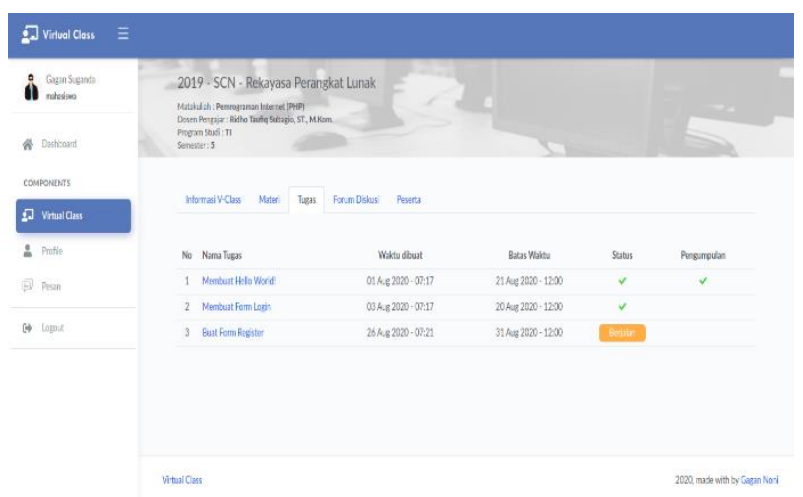

Gambar 30. Halaman Kelola Tugas

e. Halaman Kelola Forum Diskusi

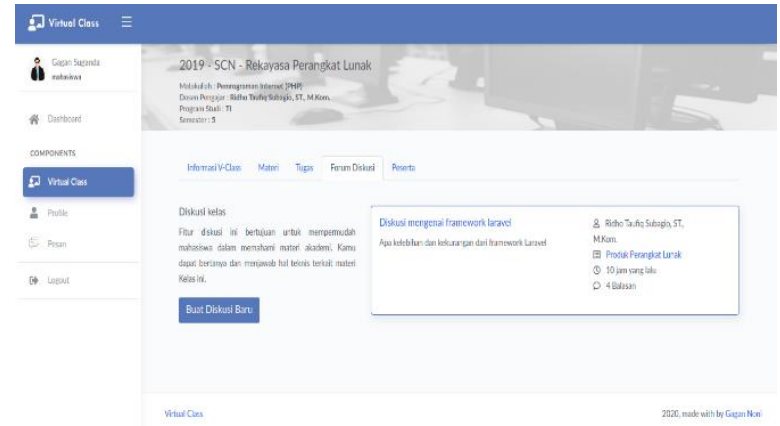

Gambar 31. Halaman Kelola Forum Diskusi

f. Halaman Forum Pesan

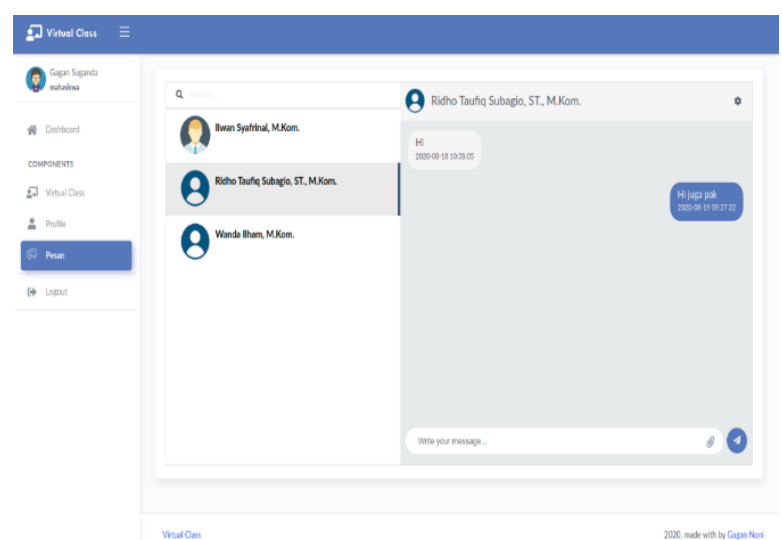

Gambar 32. Halaman Forum Pesan

Rancang Bangun Aplikasi Virtual Class Sebagai Media Pembelajaran Menggunakan Framework CodeIgniter Studi Kasus Universitas CIC Cirebon (Gagan Suganda, Noni Apriliani Yulia Putri, Ridho Taufiq, Victor Asih) 


\section{KESIMPULAN DAN SARAN}

\subsection{Kesimpulan}

Dari masalah yang telah penulis uraikan, dapat disimpulkan sebagai berikut:

1. Aplikasi yang telah dibuat dapat diterapkan sebagai salah satu fasilitas media pembelajaran online (virtual class) di Universitas CIC Cirebon untuk mengurangi permasalahan yang sering terjadi berkenaan dengan pembelajaran manual (tatap muka). Aplikasi ini dapat memudahkan pihak BAAK dalam mengatur jadwal perkuliahaan yang penuh dengan membuatkan jadwal virtual class sebagai pengganti pembelajaran diruang kelas serta memudahkan dosen maupun mahasiswa dalam melakukan pembelajaran jarak jauh (virtual class) tanpa terhalang oleh ruang dan waktu.

2. Berdasarkan hasil implementasi terhadap aplikasi yang telah dibuat, dapat disimpulkan bahwa aplikasi ini dapat diterapkan untuk membantu pihak BAAK dalam mengatur jadwal perkuliahaan yang penuh dengan membuatkan jadwal virtual class sebagai pengganti pembelajaran diruang kelas serta memudahkan dosen maupun mahasiswa dalam melakukan pembelajaran jarak jauh (virtual class) tanpa terhalang oleh ruang dan waktu.

3. Aplikasi virtual class ini dapat digunakan untuk membantu pihak BAAK dalam mengatur jadwal perkuliahaan yang penuh dengan membuatkan jadwal virtual class sebagai pengganti pembelajaran diruang kelas.

\subsection{Saran}

Adapun saran perihal pembuatan Rancang Bangun Aplikasi Virtual Class Sebagai Media

Pembelejaran Menggunakan Framework CodeIgniter dalam proyek ini adalah sebagai berikut:

1. Belum adanya fungsi pembelajaran online menggunakan live video.

2. Belum adanya fungsi pembelajaran online menggunakan live recording.

3. Belum adanya fungsi pembuatan soal pilihan ganda dalam pembuatan tugas beserta pengecekan jawabansecara otomatis.

4. Belum adanya notifikasi penerimaan pesan dan notifikasi forum diskusi.

\section{DAFTAR PUSTAKA}

[1] Darisman dan M.W. Haldi, "Design and Development of Pharmaceutical Company Information System Based On Website Using The Waterfall Model 3990", International Journal of Soft Computing and Engineering (IJRTE), vol. 9, no. 4, November 2019.

[2] R.W. Rhomdani, "Pengembangan Virtual Class Matematika Berbasis Web Menggunakan Moodle dan Wordpress di Universitas Muhammadiyah Jember", Universitas Muhammadiyah Jember, vol. 1, no.1, pp. 19-31, 2016.

[3] E. Nurfalah, "Optimalisasi E-Learning Berbasis Virtual Class dengan Google Classroom sebagai Media Pembelajaraan Fisika”, Physics Education Research Journal, vol. 1, no. 1, pp. 46-55, 2019.

[4] Sohibun dan F.Y. Ade, "Pengembangan Media Pembelajaran Berbasis Virtual Class Berbantuan Google Drive”, Tadris: Jurnal Keguruan dan Ilmu Tarbiyah, vol. 2, no.2, pp. 121-129, 2017.

[5] Badan Pengembangan dan Pembinaan Bahasa, "Kamus Besar Bahasa Indonesia", KBBI Daring, 2016 [Online]. Tersedia : https://kbbi.kemdikbud.go.id/entri/virtual [Diakses : 13 Mei 2020]

[6] Badan Pengembangan dan Pembinaan Bahasa, "Kamus Besar Bahasa Indonesia", KBBI Daring, 2016 [Online]. Tersedia : https://kbbi.kemdikbud.go.id/entri/kelas [Diakses : 13 Mei 2020]

[7] T. Tafonao, "Peran Media Pembelajaran Dalam meningkatkan Minat Belajar Mahasiswa", Jurnal Komunikasi Pendidikan, vol. 2, no.2, pp. 105, Juli 2018.

[8] A.F. Dwi. Sistem Absensi Dengan Menggunakan Teknologi RFID dan SMS Gateway Studi Kasus STMIK CIC. Proyek Teknik Informatika, STMIK CIC, Cirebon, 2018.

[9] Sidik dan H.I. Pohan, "Pemrograman Web dengan HTML". Bandung: CV. Informatika, 2001, 12.

[10] Saputra dan F. Agustin, "Pemrograman CSS untuk Pemula". Jakarta: PT Elex Media Komputindo, 2011, 1-7. 
[11] Kadir, "From Zero to A Pro HTML 5", Edisi 1. Yogyakarta: CV. Andi Offset, 2013, 11-23.

[12] D.D. Prasetyo, “Administrasi Database Server MySQ”L, Jakarta: PT Elex Media Komputindo, 2003.

[13] Sidik, "Framework CodeIgniter 3", Bandung: Informatika Bandung, 2018, 1-39.

[14] M. Lusiana, "Sistem Pendukung Keputusan Penilaian Kinerja Dosen di STMIK CIC Menggunakan Metode AHP", Proyek Teknik Informatika, STMIK CIC, Cirebon, 2018, 9.

[15] Widodo dan Herlawati, "Menggunakan UML", Bandung: Informatika, 2011, 6-22.

[16] Yuni Sugiarti, "Analisis dan Perancangan UML (Unified Modeling Language)", Yogyakarta: Graha Ilmu, 2013, 22-30.

[17] H. Tarmizi, "Pengertian Sublime Text", Hasan Tarmizi, 2017 [Online]. Tersedia : https://hasantarmizi.blogspot.com/2017/04/pengertian-sublime-text.html [Diakses 14 Mei 2020]

[18] PT. Cloud Hosting Indonesia, "XAMPP", Kamus Hosting, 2015-2020 [Online]. Tersedia: https://idcloudhost.com/kamus-hosting/xampp/ [Diakses 14 Mei 2020]

[19] Zakaria, "Pengertian Browser beserta Fungsinya Browser dan Cara Kerjanya", nesabamedia, 2019 [Online]. Tersedia: https://www.nesabamedia.com/pengertian-dan-fungsi-web-browser/ [Diakses 19 Juli 2020] 